\title{
TINGKAT ADOPSI PENGGUNAAN PUPUK HAYATI \\ PADA BUDIDAYA PADI SAWAH (Oryza sativa L.) DI KECAMATAN BUNGURSARI KOTA TASIKMALAYA
}

\author{
Muhammad Rafiudin*, Siswoyo, Ait Maryani \\ Program Studi Penyuluhan Pertanian Berkelanjutan, Jurusan Pertanian, \\ Politeknik Pembangunan Pertanian Bogor \\ Jl. Aria Surialaga No. 1 (d//h Cibalagung), Pasir Jaya, Bogor Barat, Bogor 16119 \\ *Corresponding author: rafiudin.14101998@gmail.com
}

\begin{abstract}
In lowland rice cultivation, farmers use chemical fertilizers without paying attention to the impact. If chemical fertilizers are not balanced with biological fertilizers, the organic content at paddy fields will decrease. This study aims to analyze the level of adoption, the factors that influence the adoption, and the strategies to increase the adoption of using biological fertilizers. This research was held in the Villages of Sukajaya, Sukamulya, and Sukarindik, Bungursari district, Tasikmalaya City, from April to June 2021. The research samples consisted of 71 farmers who were members of farmer groups. The samples were determined by using slovin's formula. The variables of this study consist of internal factors, external factors, characteristics of innovation, and the level of adoption. Primary data was collected in the questionnaire form. The data was processed using descriptive analysis, multiple linear regression analysis, and SWOT analysis. The results of the study regarding the level of adoption of the use of biological fertilizers were in the medium category with a percentage of $49.3 \%$. Factors that influence the level of adoption of biological fertilizers were formal education with a value of $0.026<0.05$, the relative advantage with a value of $0.001<0.05$, and the complexity with a value of $0.001<0.05$. The strategy to increase adoption using the SO strategy by maximizing to take advantage of farmer groups' opportunities. For example, maximizing guidance to farmers through outreach activities to increase the use of biofertilizers and demonstrations on how to make biofertilizers.
\end{abstract}

\section{Keyword : farmer adoption, innovation characteristics, biofertilizer}

\begin{abstract}
Abstrak: Pada budidaya padi sawah petani terbiasa menggunakan pupuk kimia tanpa memperhatikan dampak yang ditimbulkan. Penggunaan pupuk kimia apabila tidak diimbangi dengan pupuk hayati maka kandungan organik tanah sawah akan berkurang. Penelitian ini bertujuan untuk menganalisis tingkat adopsi, faktor yang memengaruhi adopsi serta merumuskan strategi peningkatan adopsi penggunaan pupuk hayati. Penelitian ini dilakukan di Kelurahan Sukajaya, Sukamulya dan Sukarindik, Kecamatan Bungursari, Kota Tasikmalaya pada April hingga Juni 2021. Sampel penelitian sebanyak 71 petani yang tergabung dalam kelompok tani. Sampel ditentukan menggunakan rumus slovin. Variabel penelitian ini terdiri atas faktor internal, faktor eksternal, karakteristik inovasi dan tingkat adopsi. Pengumpulan data primer menggunakan instrumen berupa kuesioner. Data diolah menggunakan analisis deskriptif, analisis regresi linier berganda serta analisis SWOT. Hasil penelitian mengenai tingkat adopsi penggunaan pupuk hayati berada pada kategori sedang dengan persentase $49,3 \%$. Faktor yang memengaruhi tingkat adopsi penggunaan pupuk hayati yaitu pendidikan formal dengan nilai $0,026<0,05$, keuntungan relatif dengan nilai $0,001<0,05$ serta kerumitan dengan nilai $0,001<0,05$. Strategi untuk meningkatkan adopsi dilakukan dengan strategi SO yaitu dengan memaksimalkan
\end{abstract}


kekuatan untuk memanfaatkan peluang yang ada pada kelompok tani. Beberapa upaya yang dilakukan dengan memaksimalkan pembinaan kepada petani melalui kegiatan penyuluhan untuk meningkatkan penggunaan pupuk hayati serta demonstrasi cara pembuatan pupuk hayati.

Kata kunci: adopsi petani, karakteristik inovasi, pupuk hayati

\section{PENDAHULUAN}

Sektor pertanian masih menjadi sektor unggulan dalam memenuhi kebutuhan pangan masyarakat kecamatan Bungursari salah satunya sektor pangan yaitu komoditas padi. Padi merupakan sumber makanan pokok masyarakat di Kecamatan Bungursari. Tanaman padi merupakan tanaman penghasil beras yang produksinya diupayakan ketersediaannya sepanjang tahun karena dibutuhkan sebagai bahan makanan pokok masyarakat Indonesia termasuk masyarakat di Kecamatan Bungursari.

Menurut Badan Pusat Statistik (2021) produksi padi dikonversikan menjadi beras untuk konsumsi pangan penduduk, produksi padi sepanjang Januari hingga September 2020 setara dengan 26,06 juta ton beras, atau mengalami penurunan sebesar 856,49 ribu ton (3,18\%) dibandingkan produksi tahun 2019 yang sebesar 26,91 juta ton. Sementara itu, potensi produksi beras sepanjang Oktober hingga Desember 2020 sebesar 5,57 juta ton beras. Dengan demikian, potensi produksi beras pada 2020 diperkirakan mencapai 31,63 juta ton beras, atau mengalami kenaikan sebesar 314,10 ribu ton $(1,00 \%)$ dibandingkan dengan produksi beras tahun 2019 yang sebesar 31,31 juta ton. Seperti yang kita ketahui bahwasannya Indonesia sebagai negara tertinggi yang mengonsumsi beras di dunia. Dalam hal ini produksi beras pada tahun 2020 hanya meningkat sebesar 1,00 persen dari tahun 2019. Oleh karena itu untuk mencukupi kebutuhan beras bagi penduduk Indonesia perlu adanya peningkatan produktivitas padi agar kebutuhan beras dapat terpenuhi.

Berdasarkan rencana kerja Kecamatan Bungursari, sebanyak $42,85 \%$ petani belum melaksanakan penerapan teknologi pada budidaya padi sawah salah satunya penerapan pupuk hayati sehingga tingkat produktivitas padi belum tercapai secara maksimal. Peningkatan produktivitas padi dapat dilakukan dengan cara menerapkan pupuk hayati.
Penerapan pupuk hayati di lapangan menunjukkan bahwa para petani masih kurang untuk memperoleh dan menerima pengetahuan dalam penerapan penggunaan pupuk hayati, maka dari itu petani belum dapat berperan sendiri dalam pengambilan keputusan adopsi penggunaan pupuk hayati, sehingga perlu adanya peningkatan penggunaan pupuk hayati agar produktivitas padi dapat meningkat. Sejalan dengan perkembangan dan kemajuan teknologi di bidang pemupukan serta terjadinya perubahan status hara di dalam tanah maka kebutuhan pemupukan harus sesuai dengan kebutuhan unsur hara yang diperlukan oleh tanaman. Unsur-unsur hara utama yang perlu ditambahkan pada pemupukan tanaman padi meliputi nitrogen, fosfor, dan kalium. Pada umumnya unsur-unsur tersebut diperoleh dari penambahan pupuk anorganik (kimia).

Penggunaan bahan kimia buatan baik pupuk maupun pestisida untuk peningkatan produksi pertanian dapat merusak lingkungan. Penggunaan pupuk kimia yang berlebihan menyebabkan polusi udara dan air tanah serta meningkatkan kandungan hara di perairan. Dampak negatif lain terhadap ekosistem tanah adalah pengerasan tanah, penurunan bahan organik, kontaminasi logam berat, resistensi hama dan penyakit tertentu. Salah satu usaha yang dilakukan untuk mengatasi masalah tersebut adalah dengan penggunaan pupuk hayati (biofertilizer) yang mampu meningkatkan efisiensi pemupukan dan dapat meningkatkan bahan organik tanah sawah. Selain meningkatkan bahan organik tanah, pupuk hayati dapat mengurangi penggunaan pupuk anorganik, menambah kesuburan tanah dan dapat menjaga kelestarian lingkungan hidup guna mendukung sistem pertanian yang berkelanjutan sehingga tingkat produktivitas dapat meningkat.

Pupuk hayati dapat diartikan sebagai inokulan berbahan aktif organisme hidup yang berfungsi untuk menambah hara tertentu atau memfasilitasi tersedianya hara tanah bagi tanaman. Pupuk hayati digunakan sebagai 
kolektif untuk semua kelompok fungsional mikroba tanah. Kelompok fungsional mikroba tanah terdiri dari bakteri, fungi, hingga alga yang berfungsi sebagai penyedia hara dalam tanah sehingga dapat tersedia bagi tanaman (Saraswati, 2012). Menurut Hidayatullah (2014), pupuk hayati dapat meningkatkan efisiensi pemupukan, kesuburan dan kesehatan tanah. Bakteri di lingkungan rhizosfer berperan penting dalam peningkatan nutrisi yang dapat tersedia dan dapat mempertahankan siklus unsur hara makro N. Berdasarkan permasalahan dan potensi di lapangan penulis mengambil judul "Tingkat Adopsi Penggunaan Pupuk Hayati Pada Budidaya Padi Sawah (Oryza sativa L.) di Kecamatan Bungursari Kota Tasikmalaya"

Tujuan dari penelitian yaitu: 1) menganalisis secara deskriptif tingkat adopsi penggunaan pupuk hayati pada budidaya padi sawah, 2) menganalisis faktor-faktor yang memengaruhi tingkat adopsi penggunaan pupuk hayati pada budidaya padi sawah baik faktor internal, faktor eksternal dan karakteristik inovasi, 3) menyusun strategi untuk meningkatkan adopsi penggunaan pupuk hayati pada budidaya padi sawah.

\section{METODE PENELITIAN}

Penelitian ini telah dilaksanakan pada bulan April hingga Juni 2021 di Kelurahan Sukajaya, Kelurahan Sukamulya dan Kelurahan Sukarindik, Kecamatan Bungursari Kota Tasikmalaya. Populasi pada penelitian ini adalah petani yang tergabung dalam anggota kelompok tani di tiga kelurahan yaitu Kelurahan Sukajaya, Kelurahan Sukamulya dan Kelurahan Sukarindik. Setiap kelurahan dipilih satu kelompok tani aktif yaitu Poktan Harapan Warga di Kelurahan Sukajaya dengan jumlah anggota 98 orang, Poktan Mulya Tani I di Kelurahan Sukamulya dengan jumlah anggota 99 orang, dan Poktan Suka Mekar II di
Kelurahan Sukarindik dengan jumlah anggota 42 orang.

Penelitian ini menggunakan metode penelitian kuantitatif. Sugiyono (2013) menyatakan bahwa metode penelitian kuantitatif dapat diartikan sebagai metode penelitian yang berlandaskan pada filsafat positivisme, digunakan untuk meneliti pada populasi atau sampel tertentu, teknik pengambilan sampel pada umumnya dilakukan secara random, pengumpulan data menggunakan instrumen penelitian, analisis data bersifat kuantitatif/statistik, dengan tujuan untuk menguji hipotesis yang telah ditetapkan.

Berdasarkan populasi yang terdapat pada kelompok tani di tiga kelurahan sebanyak 239 orang, untuk menentukan jumlah sampel menggunakan rumus slovin sehingga didapat jumlah sampel sebanyak 71 orang dapat dilihat pada Tabel 1.

Variabel penelitian ini terdiri dari variabel independen yaitu faktor internal, faktor eksternal dan karakteristik inovasi. Sedangkan variabel dependen yaitu tingkat adopsi penggunaan pupuk hayati. Variabel independen faktor internal $\left(\mathrm{X}_{1}\right)$ terdiri dari umur, pendidikan formal, lama usahatani dan luas lahan usahatani. Variabel independen faktor eksternal $\left(\mathrm{X}_{2}\right)$ terdiri dari kegiatan penyuluhan, sarana dan prasarana dan peran penyuluh. Variabel independen karakteristik inovasi $\left(\mathrm{X}_{3}\right)$ terdiri dari keuntungan relatif, kesesuaian, kerumitan, dapat diamati dan dapat diuji coba. Sedangkan variabel dependen tingkat adopsi penggunaan pupuk hayati (Y) meliputi pengetahuan, persuasi, keputusan, implementasi dan konfirmasi.

Instrumen penelitian sebelum digunakan harus diuji validitas dan reliabilitasnya untuk mengetahui kelayakan dan kebenarannya. Berdasarkan uji validitas dan reliabilitas yang dilakukan pada 15 orang responden sehingga $r$ tabelnya sebesar 0,553. Oleh karena itu,

Tabel 1. Jumlah populasi dan sampel

\begin{tabular}{lccc}
\multicolumn{1}{c}{ Desa/Kelurahan } & Kelompok Tani & Jumlah Anggota (Orang) & Jumlah Sampel (Orang) \\
\hline Sukajaya & Harapan Warga & 98 & $98 / 239 \times 71=29$ \\
Sukamulya & Mulya Tani I & 99 & $99 / 239 \times 71=29$ \\
Sukarindik & Suka Mekar II & 42 & $42 / 239 \times 71=13$ \\
\hline & Jumlah & 239 & 71 \\
\hline
\end{tabular}

Sumber: Olahan Data Primer, 2021 
hasil uji validitas dari 54 soal yang diujikan terdapat sepuluh soal yang tidak valid dikarenakan nilai $r$ hitung $<0,553$. Sedangkan hasil uji reliabilitas yang dilakukan dapat terlihat pada nilai Cronbach's Alpha sebesar 0,86 sehingga $>0,60$, sehingga dapat dikatakan reliabel. Instrumen penelitian yang digunakan dalam penelitian ini hanya instrumen yang valid dan reliabel sehingga soal isntrumen yang tidak valid dan reliabel tidak digunakan. (Sugiyono, 2013).

Variabel penelitian ini terdiri atas variabel bebas dan variabel terikat. Variabel bebas terdiri atas faktor internal, faktor eksternal dan karakteristik inovasi. Sedangkan untuk variabel terikat yaitu tingkat adopsi penggunaan pupuk hayati yang terdiri atas beberapa indikator yaitu pengetahuan, persuasi, keputusan, implementasi dan konfirmasi. Jenis data penelitian ini terdiri dari data primer dan sekunder. Teknik pengumpulan data data primer yaitu melalui wawancara terstruktur, observasi dan hasil dari kuesioner. Sedangkan data sekunder bersumber dari hasil penelitian, programa BPP Indihiang dan Instansi terkait. Jenis analisis data yang digunakan adalah analisis deskriptif, analisis regresi linier berganda dan analisis SWOT.

\section{HASIL DAN PEMBAHASAN}

\section{Faktor Internal}

Faktor internal yang diamati pada penelitian ini meliputi umur, pendidikan formal, lama usahatani dan luas lahan usahatani. Rincian faktor internal secara lengkap dapat dilihat pada Tabel 2.

Data BPS (2021) membedakan penduduk usia penduduk menjadi 2 kategori, yang pertama usia produktif (15 - 64 tahun) dan kedua usia tidak produktif $(<15$ tahun dan $>65$ ). Tabel 1 menunjukkan bahwa kisaran usia petani antara $36-88$ tahun dengan total responden 71 petani responden, dari data di atas kedua kategori tersebut terdapat perbedaan sebesar $(8 \%)$ antara usia produktif dan usia tidak produktif dengan sebaran data usia produktif sebanyak 38 petani responden (54\%) sedangkan usia tidak produktif yaitu sebanyak 33 orang (46\%), maka umur petani responden pada saat penelitian berada pada kategori produktif.

Susanti et al., (2016) menyatakan bahwa petani berumur 30-59 tahun memiliki fisik yang potensial untuk mendukung kegiatan usahatani, dinamis, kreatif dan cepat dalam menerima inovasi teknologi baru. Hal ini sejalan dengan penelitian Novita et al., (2016) bahwa petani yang berumur produktif akan

Tabel 2. Sebaran faktor internal penelitian

\begin{tabular}{|c|c|c|c|c|}
\hline No & Faktor internal & Kategori & Jumlah responden (Orang) & Persentase $(\%)$ \\
\hline \multirow{4}{*}{\multicolumn{2}{|c|}{ 1. Umur (tahun) }} & $36-49$ & 8 & 11,3 \\
\hline & & $50-62$ & 30 & 42,3 \\
\hline & & $63-75$ & 29 & 40,8 \\
\hline & & $76-88$ & 4 & 5,6 \\
\hline \multicolumn{3}{|c|}{ Total } & 71 & 100 \\
\hline \multirow[t]{5}{*}{2.} & Pendidikan formal (tahun) & $3-6$ & 39 & 54,9 \\
\hline & & $7-9$ & 14 & 19,7 \\
\hline & & $10-12$ & 18 & 25,4 \\
\hline & & $13-15$ & 0 & 0,0 \\
\hline & Total & & 71 & 100 \\
\hline & Lama usahatani (tahun) & $10-16$ & 13 & 18,3 \\
\hline & & $17-22$ & 28 & 39,4 \\
\hline & & $23-28$ & 19 & 26,8 \\
\hline & & $29-34$ & 11 & 15,5 \\
\hline \multirow{5}{*}{\multicolumn{2}{|c|}{$\begin{array}{c}\text { Total } \\
\text { Luas lahan usahatani (Ha) }\end{array}$}} & & 71 & 100 \\
\hline & & $0,05-0,55$ & 61 & 85,9 \\
\hline & & $0,56-1,05$ & 9 & 12,7 \\
\hline & & $1,06-1,55$ & 0 & 0,0 \\
\hline & & $1,56-2,05$ & 1 & 1,4 \\
\hline & Total & & 71 & 100 \\
\hline
\end{tabular}

Sumber: Olahan Data Primer, 2021 
lebih mudah memahami hal-hal baru dalam usahatani sehingga dapat meningkatkan produksi padi sawahnya.

Pendidikan formal yang ditempuh individu dapat memengaruhi tingkat berpikir dan penalarannya dalam mengambil keputusan. Hasil penelitian yang dilakukan pada petani responden menunjukkan bahwa pendidikan formal di wilayah responden termasuk kedalam kriteria 3-6 tahun dengan jumlah sekitar 39 petani responden dengan persentase 54,9\%. Hasil observasi dan wawancara yang telah dilakukan, tingkat pendidikan petani berhubungan dengan umur petani dimana mayoritas petani memiliki usia yang tua. Dalam penelitian Padillah et al., (2018) menyatakan bahwa pendidikan formal rendah disebabkan sulitnya mendapatkan biaya pendidikan dan rendahnya kesadaran serta peran orang tua jaman dahulu untuk menyekolahkan anaknya hingga ke jenjang yang lebih tinggi.

Lama usahatani menunjukkan sebagian besar responden memiliki pengalaman yang mumpuni yaitu berkisar $17-22$ tahun lama usahatani atau sekitar 39,4\%. Semakin lama pengalaman usahatani maka petani akan memiliki keterampilan dan pengetahuan yang lebih luas mengenai usahatani (Noer et al., 2018). Hasil penelitian ini sejalan dengan penelitian Muchtar et al., (2014), bahwa semakin berpengalaman petani dalam berusahatani, petani semakin tahu dan memahami pengelolaan usahatani.

Luas lahan usahatani menunjukkan bahwa sebagian besar petani responden memiliki luas lahan antara $0,05-0,55$ ha. Luas lahan tersebut tergolong lahan yang sempit dengan persentase $85,9 \%$ sebanyak 61 orang petani responden. Hasil penelitian ini sejalan dengan penelitian Yahya et al., (2012), bahwa sempitnya lahan usahatani yang dikelola petani disebabkan oleh adanya pembagian warisan, dijadikan perumahan dan dijual untuk keperluan hidup.

\section{Faktor Eksternal}

Faktor eksternal yang diamati pada penelitian ini meliputi kegiatan penyuluhan, sarana dan prasarana serta peran penyuluh. Rincian faktor eksternal secara lengkap dapat dilihat pada Tabel 3.

Kegiatan penyuluhan di Kecamatan Bungursari termasuk kedalam kategori sedang dengan persentase sebesar $45,1 \%$. Hal ini berarti kegiatan penyuluhan dalam meningkatkan adopsi penggunaan pupuk hayati sudah berjalan dengan cukup baik. Selain kegiatan penyuluhan, mayoritas petani mendapatkan informasi dari rekan petani lainnya dan sebagian ada yang dari penyuluh pertanian. Sarana dan prasarana di Kecamatan Bungursari termasuk kedalam kategori sedang dengan persentase sebesar $38,0 \%$. Hal ini berarti sarana dan prasarana yang ada di Kecamatan Bungursari masing-masing petani sudah dapat mengakses dan mempergunakan sarana prasarana yang ada akan tetapi masih ada akses yang belum terpenuhi dan belum bisa menunjang kegiatan usahataninya.

Tabel 3. Sebaran faktor eksternal penelitian

\begin{tabular}{ccccc}
\hline No & Faktor Ekternal & Kategori & Jumlah Responden (Orang) & Persentase (\%) \\
\hline 1. & Kegiatan Penyuluhan & Rendah & 27 & 38,0 \\
& & Sedang & 32 & 45,1 \\
& & Tinggi & 12 & 16,9 \\
\hline & Total & & 71 & 100 \\
\hline 2. & Sarana dan Prasarana & Rendah & 19 & 26,8 \\
& & Sedang & 27 & 38,0 \\
& & Tinggi & 25 & 35,2 \\
\hline & Total & & 71 & 100 \\
\hline 3. & Peran Penyuluh & Rendah & 24 & 33,8 \\
& & Sedang & 41 & 57,7 \\
& & Tinggi & 6 & 8,5 \\
\hline & Total & & 71 & 100 \\
\hline
\end{tabular}

Sumber: Olahan Data Primer, 2021 
Hasil ini sejalan dengan penelitian Rimbawati et al., (2018) yang menyatakan bahwa fungsi tugas kelompok adalah hal-hal yang harus dilakukan didalam kelompok agar kelompok dapat mencapai tujuannya yaitu memfasilitasi sarana prasarana dan mengoordinir usaha-usaha kelompok yang menyangkut masalah-masalah bersama.

Peran penyuluh di Kecamatan Bungursari termasuk kedalam kategori sedang dengan persentase sebesar $57,7 \%$. Hal ini menunjukkan bahwa peran penyuluh pertanian dinilai sudah berjalan dengan cukup baik. Penyuluh pertanian memiliki peran penting untuk memberi dukungan dan semangat kepada petani dan anggota kelompok tani agar mau dan mampu meningkatkan tingkat adopsi penggunaan pupuk hayati pada budidaya padi sawah. Hasil ini sejalan dengan penelitian Sundari et al. (2015) yang menyebutkan bahwa penyuluh sebagai agen pembaharu adalah penyuluh senantiasa harus dapat memengaruhi sasarannya agar dapat merubah dirinya sendiri kearah kemajuan.

\section{Karakteristik Inovasi}

Karakteristik inovasi merupakan sifat inovasi yang dapat memengaruhi kecepatan petani responden dalam mengadopsi sebuah inovasi pertanian yang akan meningkatkan produktivitas pada usahatani. Karakteristik inovasi adalah kriteria sebuah sistem informasi yang menentukan cepatnya adopsi inovasi oleh pengguna (Amala et al., 2014). Karakteristik inovasi menurut Amala et al., (2014), terdiri atas 5 elemen utama, yaitu keuntungan relatif, kesesuaian, kerumitan, kemungkinan untuk dicoba dan kemungkinan untuk diamati/ dirasakan hasilnya. Rincian karakteristik inovasi secara lengkap dapat dilihat pada Tabel 4. Berdasarkan hasil analisis menunjukkan bahwa indikator keuntungan relatif pada variabel karakteristik inovasi di Kecamatan Bungursari termasuk kedalam kategori sedang dengan persentase sebesar $54,9 \%$. Hal ini menandakan bahwa para petani dalam penggunaan pupuk hayati dapat meningkatkan produktivitas padi sawah sehingga tingkat pendapatan petani dapat meningkat. Keadaan di lapangan petani melihat secara langsung dampak penggunaan pupuk hayati pada lahan petak percontohan sehingga petani mengetahui tingkat produktivitas padi meningkat.

Indikator kesesuaian pada variabel karakteristik inovasi tingkat adopsi penggunaan pupuk hayati tergolong kedalam kategori sedang dengan persentase $90,1 \%$. Hasil analisis di lapangan bahwasanya petani dalam penggunaan pupuk hayati sebagian sudah ada

Tabel 4. Sebaran karakteristik inovasi penelitian

\begin{tabular}{|c|c|c|c|c|}
\hline No & Karakteristik inovasi & Kategori & Jumlah responden (Orang) & Persentase $(\%)$ \\
\hline \multirow{3}{*}{\multicolumn{2}{|c|}{ 1. Keuntungan relatif }} & Rendah & 25 & 35,2 \\
\hline & & Sedang & 39 & 54,9 \\
\hline & & Tinggi & 7 & 9,9 \\
\hline \multicolumn{3}{|c|}{ Total } & 71 & 100 \\
\hline \multirow{3}{*}{\multicolumn{2}{|c|}{ 2. Kesesuaian }} & Rendah & 3 & 4,2 \\
\hline & & Sedang & 64 & 90,1 \\
\hline & & Tinggi & 4 & 5,6 \\
\hline \multicolumn{3}{|c|}{ Total } & 71 & 100 \\
\hline \multirow{3}{*}{\multicolumn{2}{|c|}{ 3. Kerumitan }} & Rendah & 34 & 47,9 \\
\hline & & Sedang & 25 & 35,2 \\
\hline & & Tinggi & 12 & 16,9 \\
\hline \multicolumn{3}{|c|}{ Total } & 71 & 100 \\
\hline \multirow{3}{*}{\multicolumn{2}{|c|}{ 4. Dapat diamati }} & Rendah & 69 & 97,2 \\
\hline & & Sedang & 2 & 2,8 \\
\hline & & Tinggi & 0 & 0,0 \\
\hline \multicolumn{3}{|c|}{ Total } & 71 & 100 \\
\hline \multirow{3}{*}{\multicolumn{2}{|c|}{ 5. Dapat diuji coba }} & Rendah & 31 & 43,7 \\
\hline & & Sedang & 26 & 36,6 \\
\hline & & Tinggi & 14 & 19,7 \\
\hline \multicolumn{3}{|c|}{ Total } & 71 & 100 \\
\hline
\end{tabular}

Sumber: Olahan Data Primer, 2021 
lahan yang dapat menyesuaikan dengan pupuk hayati dan sebagian lahan ada yang belum sesuai. Kebanyakan petani dalam penggunaan pupuk menggunakan pupuk kimia, sehingga dalam penggunaan pupuk hayati perlu di imbangi dengan penggunaan pupuk organik agar pupuk hayati dapat bereaksi dengan sempurna.

Indikator kerumitan pada variabel karakteristik inovasi tergolong kedalam kategori rendah dengan persentase 47,9\%. Hal ini sesuai dengan observasi di lapangan bahwasannya kerumitan dalam penggunaan pupuk hayati tergolong cukup rendah karena petani sudah mulai mengerti tentang penggunaan pupuk hayati dan petani juga tidak perlu melakukan hal-hal sulit dalam menerapkan penggunaan pupuk hayati. Begitupun untuk membuat agen hayati atau pupuk hayati petani hanya perlu menyiapkan bahan-bahan yang mudah didapat salah satunya seperti akar bambu.

Indikator dapat diamati pada variabel karakteristik inovasi tergolong kedalam kategori rendah dengan persentase 97,2\%. Hal ini sesuai dengan di lapangan bahwasanya dalam pelaksanaan pembuatan petak percontohan penggunaan pupuk hayati tidak terlalu terlihat perbedaannya secara signifikan. Hal ini dipengaruhi oleh beberapa faktor salah satunya yaitu minimnya kandungan organik dalam tanah sawah sehingga pupuk hayati tidak bisa bereaksi secara maksimal.

Indikator dapat diuji coba pada variabel karakteristik inovasi tergolong ke dalam kategori rendah dengan persentase $43,7 \%$. Hal ini sesuai dengan hasil observasi di lapangan bahwasanya para petani responden masih enggan mencoba suatu inovasi tanpa adanya bukti secara nyata di lapangan. Petani cenderung akan menerapkan suatu inovasi jika petani sudah melihat secara nyata di lapangan. Maka dari itu untuk meningkatkan tingkat ketercobaan penggunaan pupuk hayati dilakukan pembuatan petak percontohan pada lahan petani.

\section{Tingkat Adopsi Penggunaan Pupuk Hayati}

Hasil analisis deskriptif pada penelitian ini berdasarkan data yang diperoleh melalui kuesioner dapat dilihat pada Tabel 5.
Tabel 5. Persentase tingkat adopsi

\begin{tabular}{ccc}
\hline Kategori & $\begin{array}{c}\text { Jumlah Responden } \\
\text { (Orang) }\end{array}$ & Persentase (\%) \\
\hline Rendah & 33 & 46,5 \\
Sedang & 35 & 49,3 \\
Tinggi & 3 & 4,2 \\
\hline Total & 71 & 100 \\
\hline
\end{tabular}

Sumber: Olahan Data Primer, 2021

Berdasarkan Tabel 5 diketahui bahwa mayoritas petani responden memiliki tingkat adopsi sedang pada tingkatan adopsi penggunaan pupuk hayati dengan persentase $49,3 \%$. Hal ini menunjukkan bahwa tingkat adopsi penggunaan pupuk hayati masih perlu ditingkatkan oleh responden, guna meningkatkan produktivitas, meningkatkan kandungan organik tanah sawah serta kualitas tanaman padi sawah responden. Keadaan petani di lapangan dalam melakukan budidaya padi sawah petani selalu memperhatikan kondisi tanamanya tanpa memperhatikan kondisi tanah sawahnya. Hal ini disebabkan petani sudah terbiasa menggunakan pupuk kimia yang dapat dilihat langsung hasilnya. Berdasarkan pengalaman yang telah dimiliki umumnya petani sudah mengetahui tentang pupuk organik maupun pupuk hayati tetapi masih rendah dalam mengambil keputusan maupun implementasi petani di lapangan. Hal ini disebabkan oleh reaksi dari pupuk hayati yang tidak bisa dilihat secara langsung oleh petani karena reaksi dari penggunaan pupuk hayati ini membutuhkan waktu untuk dapat melihat hasilnya.

\section{Faktor yang Memengaruhi Tingkat Adopsi Penggunaan Pupuk Hayati}

Analisis mengenai faktor-faktor yang memengaruhi keputusan petani untuk mengadopsi teknologi penggunaan pupuk hayati pada budidaya padi sawah menggunakan analisis regresi linier berganda. Hasil analisis pengaruh indikator - indikator tersebut dapat dilihat pada Tabel 6 .

Hasil analisis menunjukkan bahwa variabel pendidikan formal, keuntungan relatif dan kerumitan memiliki pengaruh signifikan terhadap adopsi penggunaan pupuk hayati pada budidaya padi sawah. Adapun persamaannya adalah $\mathrm{Y}_{1}=0,974-0,020 \mathrm{X}_{1.2}+0,187 \mathrm{X}_{3.1}+$ $0,106 \mathrm{X}_{3.3}$ dengan taraf nyata $5 \%$. 
Tabel 6. Hasil analisis regresi linier berganda

\begin{tabular}{|c|c|c|}
\hline Indikator & Koefisien & Signifikansi \\
\hline $\mathrm{R}^{2}$ & 0,606 & \\
\hline Konstanta & $0,974 * * *$ & 0,000 \\
\hline $\operatorname{Umur}\left(\mathrm{X}_{1.1 .1}\right)$ & $-0,003$ & 0,233 \\
\hline $\begin{array}{l}\text { Pendidikan formal } \\
\left(\mathrm{X}_{1.2 .2}\right)^{*}\end{array}$ & $-0,020 * *$ & 0,026 \\
\hline Lama usahatani $\left(\mathrm{X}_{.1 .3}\right)$ & $-0,004$ & 0,435 \\
\hline $\begin{array}{l}\text { Luas lahan usahatani } \\
\left(\mathrm{X}_{.1 .4}\right)\end{array}$ & $-0,085$ & 0,405 \\
\hline $\begin{array}{l}\text { Kegiatan penyuluhan } \\
\left(\mathrm{X}_{2.1}\right)\end{array}$ & 0,068 & 0,161 \\
\hline $\begin{array}{l}\text { Sarana dan Prasarana } \\
\left(\mathrm{X}_{2.2}\right)\end{array}$ & 0,046 & 0,246 \\
\hline Peran penyuluh $\left(\mathrm{X}_{2.3}\right)$ & $0,102 *$ & 0,060 \\
\hline $\begin{array}{l}\text { Keuntungan relatif } \\
\left(\mathrm{X}_{3.1}\right)^{*}\end{array}$ & $0,187 * * *$ & 0,001 \\
\hline Kesesuaian $\left(\mathrm{X}_{3.2}\right)$ & 0,041 & 0,235 \\
\hline Kerumitan $\left(\mathrm{X}_{3.3}\right)^{*}$ & $0,106^{* * *}$ & 0,001 \\
\hline Dapat diamati $\left(\mathrm{X}_{3.4}\right)$ & 0,038 & 0,260 \\
\hline $\begin{array}{l}\text { Dapat diuji coba } \\
\left(\mathrm{X}_{3.5}\right) \\
\mathrm{R}^{2} \\
\text { F-hitung } \\
\text { Jumlah Observasi }\end{array}$ & $0,074 *$ & 0,054 \\
\hline
\end{tabular}

Sumber: Olahan Data Primer, 2021

Keterangan :

*** : Pengaruh nyata sig. $(\alpha=1 \%)$

** : Pengaruh nyata sig. $(\alpha=5 \%)$

* : Pengaruh nyata sig. $(\alpha=10 \%)$

Persamaan tersebut berarti bahwa pendidikan formal memberikan pengaruh sebesar 0,020 , keuntungan relatif memberikan pengaruh 0,187, dan kerumitan memberikan pengaruh sebesar 0,106 . Nilai koefisien determinasi $\left(\mathrm{R}^{2}\right)$ sebesar 0,606 yang artinya variabel yang diteliti memengaruhi adopsi penggunaan pupuk hayati sebesar $60,6 \%$ dan sisanya $(39,4 \%)$ dipengaruhi oleh faktor lain di luar penelitian ini.

\section{Pengaruh Pendidikan Formal Terhadap Tingkat Adopsi}

Pendidikan formal memiliki pengaruh signifikan terhadap adopsi penggunaan pupuk hayati dengan nilai signifikansi sebesar $0,026<$ $0,05(\alpha=5 \%)$. Hal ini menandakan semakin tinggi tingkat pendidikan maka peluang mengadopsi teknologi penggunaan pupuk hayati akan semakin besar. Hasil penelitian ini sependapat dengan Utama et al., (2007) bahwa tingkat pendidikan seseorang dapat merubah pola pikir dan daya nalar yang baik, semakin tinggi tingkat pendidikan petani akan membuat mereka semakin mengerti tentang teknologi pemupukan berimbang serta penerapannya dengan baik.

Dari hasil analisis di lapangan terlihat bahwa petani yang memiliki pendidikan tinggi lebih mudah dalam memahami informasi yang datang, lebih responsif terhadap inovasi yang disampaikan serta keinginan untuk mencoba yang tinggi. Pendidikan petani dapat ditingkatkan dengan adanya pendidikan nonformal untuk meningkatkan wawasan petani mengenai adopsi teknologi yaitu dengan cara melakukan penyuluhan. Kedepannya, pendidikan di kalangan petani dapat ditingkatkan dengan mempersiapkan generasi muda agar tertarik untuk melanjutkan usaha pertanian. Regenerasi petani sangat perlu dilakukan mengingat mayoritas petani saat ini sudah tergolong tua berkisar usia antara 36-86 tahun. Dengan melibatkan petani muda dalam kegiatan usahatani diharapkan proses adopsi terhadap teknologi pertanian dapat optimal guna meningkatkan produktivitas tanaman padi.

\section{Pengaruh Indikator Keuntungan Relatif Terhadap Tingkat Adopsi}

Nilai koefisien regresi yang dimiliki variabel keuntungan relatif yaitu 0,187 dimana nilai signifikansi $0,001<0,05(\alpha 5 \%)$ yang berarti variabel keuntungan relatif memiliki pengaruh secara signifikan terhadap adopsi penggunaan pupuk hayati. Hal ini sesuai dengan keadaan di lapangan bahwa para petani menilai cukup baik adanya keuntungan relatif saat menggunakan pupuk hayati pada budidaya padi sawah. Keuntungan teknis yang dirasakan petani yaitu meningkatkan bahan organik tanah sawah, meningkatkan mikroorganisme tanah sawah, menjaga kelestarian sumberdaya lahan pertanian dan untuk keuntungan secara ekonomi yang dirasakan petani adalah meningkatkan produktivitas padi sawah sehingga pendapatan petani dapat meningkat.

\section{Pengaruh Indikator Kerumitan Terhadap Tingkat Adopsi}

Variabel bebas selanjutnya yaitu indikator kerumitan memiliki nilai signifikansi sebesar $0,001<0,05(\alpha=5 \%)$. Hal ini menunjukkan para petani mampu mengatasi kerumitan yang ada pada teknologi inovasi pertanian yaitu penggunaan pupuk hayati. Hasil observasi di 
lapangan petani sudah mengetahui mengenai penggunaan pupuk hayati, pembuatan pupuk hayati dan pengaplikasian pupuk hayati pada budidaya padi sawah. Dalam pembuatan agen hayati ataupun pupuk hayati petani dapat menggunakan bahan baku sederhana salah satunya yaitu akar bambu. Dalam akar bambu tersebut terkandung berbagai macam bakteri dan juga sebagai sumber bakteri yang bermanfaat bagi tanaman sehingga akar bambu menjadi bahan dasar dalam pembuatan agen hayati.

Tabel 7. Matriks SWOT

\begin{tabular}{|c|c|c|}
\hline Analisis Eksternal & $\begin{array}{l}\text { Kekuatan (Strengths) } \\
\text { 1. Penyuluh pertanian } \\
\text { berperan aktif dalam } \\
\text { peningkatan penggunaan } \\
\text { pupuk hayati } \\
\text { 2. Tugas pokok dan fungsi } \\
\text { struktur organisasi } \\
\text { kelompok tani berjalan } \\
\text { dengan baik } \\
\text { 3. Pengalaman petani dalam } \\
\text { berusahatani yang } \\
\text { mumpuni } \\
\text { 4. Biaya pembuatan agen } \\
\text { hayati cukup terjangkau } \\
\text { 5. Sarana prasarana yang } \\
\text { memadai }\end{array}$ & $\begin{array}{l}\text { Kelemahan (Weaknesses) } \\
\text { 1. Umur petani relatif tua } \\
\text { 2. Pendidikan petani masih } \\
\text { rendah } \\
\text { 3. Penerapan teknologi yang } \\
\text { rendah } \\
\text { 4. Keterbatasan pengetahuan } \\
\text { petani tentang pupuk hayati } \\
\text { 5. Reaksi pupuk hayati yang } \\
\text { tidak bisa dilihat hasilnya } \\
\text { secara instan } \\
\text { 6. Kurangnya fasilitas teliti } \\
\text { terap/petak percontohan } \\
\text { penggunaan pupuk hayati }\end{array}$ \\
\hline $\begin{array}{l}\text { Peluang (Opportunities) } \\
\text { 1. Meningkatkan mikroorganisme } \\
\text { tanah sawah } \\
\text { 2. Menjaga kelestarian } \\
\text { sumberdaya lahan pertanian } \\
\text { 3. Meningkatkan kesadaran } \\
\text { masyarakat akan bahaya residu } \\
\text { pemakaian pupuk kimia } \\
\text { 4. Mengurangi ketergantungan } \\
\text { masyarakat terhadap } \\
\text { penggunaan pupuk kimia }\end{array}$ & $\begin{array}{l}\text { Strategi SO } \\
\text { 1. Meningkatkan penyuluhan } \\
\text { kepada petani melalui } \\
\text { kelompok tani dalam } \\
\text { penggunaan pupuk hayati } \\
\text { (S1,S2,S3,O1,O2) } \\
\text { 2. Melaksanakan penyuluhan } \\
\text { pertanian dengan metode } \\
\text { demonstrasi cara } \\
\text { pembuatan agen hayati } \\
\text { (S4,S5,O3,O4) }\end{array}$ & $\begin{array}{l}\text { Strategi WO } \\
\text { 1. Melaksanakan kegiatan } \\
\text { penyuluhan pertanian terkait } \\
\text { pupuk hayati secara } \\
\text { pendekatan individu maupun } \\
\text { kelompok guna } \\
\text { meningkatkan pengetahuan } \\
\text { dan kemampuan petani dalam } \\
\text { penerapan teknologi } \\
\text { (W1,W2,W3,W4,O3O4) } \\
\text { 2. Melaksanakan fasilitas teliti } \\
\text { terap/petak percontohan pada } \\
\text { lahan petani tentang } \\
\text { penggunaan pupuk hayati } \\
\text { (W5,W6, O1,O2,) }\end{array}$ \\
\hline $\begin{array}{l}\text { Ancaman (Threats) } \\
\text { 1. Serangan hama dan penyakit } \\
\text { 2. Masyarakat terbiasa } \\
\text { menggunakan pupuk kimia } \\
\text { yang praktis dengan harga } \\
\text { subsidi } \\
\text { 3. Masyarakat suka menggunakan } \\
\text { pupuk kimia karena hasilnya } \\
\text { dapat dilihat secara instan }\end{array}$ & 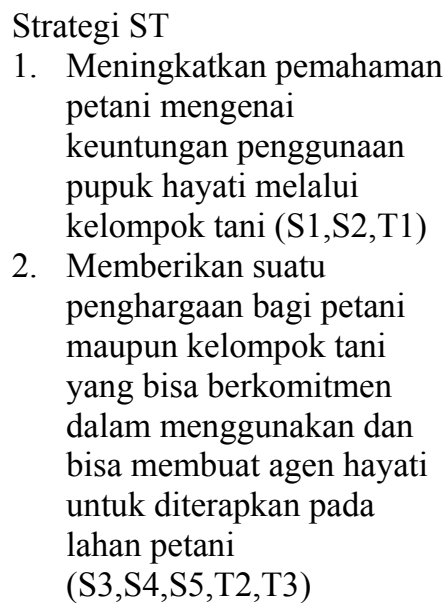 & $\begin{array}{l}\text { Strategi WT } \\
\text { 1. } \text { Meningkatkan pembinaan } \\
\text { pada petani maupun } \\
\text { kelompok tani guna } \\
\text { meningkatkan keterampilan } \\
\text { terhadap penggunaan pupuk } \\
\text { hayati (W1,W2,W3,W4,T1) } \\
\text { 2. } \\
\text { Mengembangkan } \\
\text { kemandirian petani terhadap } \\
\text { penggunaan pupuk hayati } \\
\text { (W5,W6,T2,T3) }\end{array}$ \\
\hline
\end{tabular}

Sumber: Olahan Data Primer, 2021 
Rafiudin, M., Siswoyo, Maryani, A. : Tingkat Adopsi Penggunaan Pupuk ...

Tabel 8. Internal Strategic Factors Evaluation Analysis Summary (IFAS)

\begin{tabular}{llll}
\multicolumn{1}{c}{ Faktor Internal } & Bobot & Rating & Jumlah \\
\hline Kekuatan (Strength) & & & 0,33 \\
Penyuluh pertanian berperan aktif dalam peningkatan penggunaan pupuk hayati & 0,08 & 4,00 & 0,33 \\
Tugas pokok dan fungsi struktur organisasi kelompok tani berjalan dengan baik & 0,10 & 5,00 & 0,52 \\
Pengalaman petani dalam berusahatani yang mumpuni & 0,13 & 3,00 & 0,38 \\
Biaya pembuatan agen hayati cukup terjangkau & 0,10 & 3,00 & 0,31 \\
Sarana prasarana yang memadai $\quad$ Jumlah & 0,06 & 3,00 & 0,19 \\
\hline & 0,48 & & 1,73 \\
\hline Kelemahan (Weakness) & & & 0,13 \\
Umur petani relatif tua & 0,06 & 2,00 & 0,21 \\
Pendidikan petani masih rendah & 0,10 & 2,00 \\
Penerapan teknologi yang rendah & 0,04 & 3,00 & 0,13 \\
Keterbatasan pengetahuan petani tentang pupuk hayati & 0,10 & 2,00 & 0,21 \\
Reaksi pupuk hayati yang tidak bisa dilihat hasilnya secara instan & 0,13 & 3,00 & 0,38 \\
Kurangnya fasilitas teliti terap/petak percontohan penggunaan pupuk hayati & 0,08 & 2,00 & 0,17 \\
\hline$\quad$ Jumlah & 0,52 & & 1,21 \\
\hline
\end{tabular}

Sumber: Olahan Data Primer, 2021

Tabel 9. External Strategic Factors Evaluation Analysis Summary (EFAS)

\begin{tabular}{|c|c|c|c|}
\hline Faktor Eksternal & Bobot & Rating & Jumlah \\
\hline \multicolumn{4}{|l|}{ Peluang (Opportunities) } \\
\hline Meningkatkan mikroorganisme tanah sawah & 0,17 & 5,00 & 0,86 \\
\hline Menjaga kelestarian sumberdaya lahan pertanian & 0,14 & 4,00 & 0,57 \\
\hline Meningkatkan kesadaran masyarakat akan bahaya residu pemakaian pupuk kimia & 0,11 & 4,00 & 0,46 \\
\hline Mengurangi ketergantungan masyarakat terhadap penggunaan pupuk kimia & 0,14 & 3,00 & 0,43 \\
\hline Jumlah & 0,57 & & 2,31 \\
\hline \multicolumn{4}{|l|}{ Ancaman (Threats) } \\
\hline Serangan hama dan penyakit & 0,17 & 3,00 & 0,51 \\
\hline Masyarakat terbiasa menggunakan pupuk kimia yang praktis dengan harga subsidi & 0,14 & 2,00 & 0,29 \\
\hline $\begin{array}{l}\text { Masyarakat suka menggunakan pupuk kimia karena hasilnya dapat dilihat secara } \\
\text { instan }\end{array}$ & 0,11 & 2,00 & 0,23 \\
\hline Jumlah & 0,43 & & 1,03 \\
\hline
\end{tabular}

Sumber: Olahan Data Primer, 2021

\section{Strategi Peningkatan Adopsi Penggunaan Pupuk Hayati}

Perencanaan strategi yang dilakukan dalam upaya peningkatan tingkat adopsi penggunaan pupuk hayati pada budidaya padi sawah dilakukan dengan mengalisis hasil observasi dilapangan mengenai kekuatan, kelemahan, peluang maupun ancaman yang terdapat pada kelompok tani dapat dilihat pada Tabel 7.

Hasil analisis dan penilaian terhadap variabel terpenting selanjutnya akan menghasilkan pemeringkatan strategi. Adapun hasil pemeringkatan strategi tersebut yaitu:
1. Strategi $\mathrm{S}-\mathrm{O} \quad: 1,73+2,31=4,04$

2. Strategi $\mathrm{S}-\mathrm{T} \quad: 1,73+1,03=2,76$

3. Strategi $\mathrm{W}-\mathrm{O} \quad: 1,21+2,31=3,52$

4. Strategi $\mathrm{W}-\mathrm{T} \quad: 1,21+1,03=2,24$

Berdasarkan hasil pemeringkatan, didapatkan bahwa strategi terbaik untuk meningkatkan adopsi penggunaan pupuk hayati pada budidaya padi sawah yaitu strategi SO dilakukan dengan memaksimalkan kekuatan untuk memanfaatkan peluang yang ada pada kelompok tani. Upaya yang dapat dilakukan dengan memaksimalkan pembinaan kepada petani melalui kegiatan penyuluhan secara 
anjangsana maupun secara kelompok dalam upaya meningkatkan penggunaan pupuk hayati. Hal ini dapat dilakukan dengan memanfaatkan berbagai macam media salah satunya yaitu dengan melakukan pembinaan secara rutin melalui media elektronik seperti handphone maupun melalui whatsapp group dan sejenisnya untuk saling berdiskusi antara petani dan penyuluh pertanian. Kemudian dengan melakukan kegiatan penyuluhan pertanian dengan metode demonstrasi cara pembuatan agen hayati dengan bahan baku yang mudah didapat di sekitar salah satunya yaitu akar bambu. Pada akar bambu terkandung berbagai macam bakteri yang baik untuk tanah maupun tanaman diantaranya Rhizobium,bacillus $s p$ sebagi pelarut phosphate, kalium, ZPT dan penekan phatogen, pseudomonas putida sebagai penekan pathogen, actinumycetes sebagai anti biotik, maka dari itu dilakukannya praktik pembuatan agen hayati dengan memanfaatkan akar bambu. Kegiatan demonstrasi cara dalam pembuatan agen hayati ini diharapkan petani mampu membuat agen hayati secara mandiri guna meningkatkan kandungan mikroorganisme tanah sawah serta menjaga kelestarian sumberdaya lahan pertanian.

\section{Petak Percontohan}

Untuk lebih menguatkan strategi peningkatan adopsi penggunaan pupuk hayati dilaksanakan pembuatan petak percontohan di lahan petani. Petak percontohan ini merupakan salah satu metode penyuluhan yang dilakukan peneliti pada penelitian ini. Petak percontohan terletak di Kelompok Tani Harapan Warga, Kelurahan Sukajaya yang memiliki luas $\pm 200 \mathrm{~m}^{2}$ menggunakan varietas lokal Sumatera dengan jarak tanam $25 \mathrm{~cm} \times 25 \mathrm{~cm}$. Pada petak percontohan tersebut bertujuan untuk menjadi model dalam proses pembelajaran para petani responden dalam memahami teknologi penggunaan pupuk hayati pada budidaya padi sawah. Pada petak percontohan ini dilakukan dua perlakuan yaitu satu petak menerapkan penggunaan pupuk hayati dibandingkan dengan petak yang tidak menerapkan penggunaan pupuk hayati sebagai kontrol dengan luas \pm 200 $\mathrm{m}^{2}$.

Teknis budidaya dilakukan dengan cara yang sama seperti pada umumnya petani responden lakukan budidaya padi sawah, namun pada petak percontohan dilakukan perlakuan penggunaan pupuk hayati dan yang tidak menggunakan pupuk hayati. Pupuk hayati yang digunakan ada 2 macam jenis yaitu pupuk hayati yang ada dipasaran salah satunya yaitu oryza plus dan pupuk hayati yang terbuat dari bahan utama berupa akar bambu. Aplikasi penggunaan pupuk hayati dilakukan dengan cara disemprot secara merata ke areal tanaman selama 3 kali selang 2 minggu dengan dosis 15 $\mathrm{ml}$ pupuk hayati per 1 liter air setiap kali penyemprotan. Selain melakukan penyemprotan, pada petak percontohan dilakukan pengamatan terhadap perkembangan tumbuhnya padi dilihat dari jumlah anakan, kemudian tinggi tanamannya. Pengamatan dilakukan setiap 2 minggu sekali terhadap kenampakan visual tanaman untuk mengetahui ada tidaknya pertumbuhan setelah dilakukan penyemprotan pupuk hayati.

Untuk mengetahui ada tidaknya perbedaan antara pertumbuhan tanaman padi yang menggunakan teknologi penggunaan

Tabel 10. Rata-rata hasil pengamatan pertumbuhan tanaman padi di petak percontohan

\begin{tabular}{cccc}
\hline Umur Tanaman & & Kontrol & Penggunaan Pupuk Hayati \\
\hline Tinggi Tanaman $(\mathrm{cm})$ & $3 \mathrm{MST}$ & 32,2 & 35,3 \\
& $5 \mathrm{MST}$ & 49,2 & 56,6 \\
& $7 \mathrm{MST}$ & 71,5 & 80,3 \\
& $9 \mathrm{MST}$ & 85,5 & 104,5 \\
& $11 \mathrm{MST}$ & 111,4 & 119,2 \\
\hline Jumlah Anakan per rumpun (batang) & $3 \mathrm{MST}$ & 8,5 & 10,2 \\
& $5 \mathrm{MST}$ & 18,2 & 21,2 \\
& $7 \mathrm{MST}$ & 21,4 & 26,9 \\
& $9 \mathrm{MST}$ & 20 & 24,1 \\
& $11 \mathrm{MST}$ & 21 & 25,1 \\
\hline
\end{tabular}

Sumber: Olahan Data Primer, 2021 
pupuk hayati dan pertumbuhan tanaman yang tanpa perlakuan teknologi dilakukan dengan uji independent t-test. Dari hasil Uji independent $t$ test menunjukkan bahwa tinggi tanaman padi pada petak percontohan memiliki nilai signifikansi sebesar $0,667>0,05(\alpha=5 \%)$. Hal ini menandakan bahwa untuk tinggi tanaman padi tidak terdapat perbedaan yang signifikan antara tinggi tanaman padi dengan perlakuan pupuk hayati dan yang tidak menggunakan perlakuan pupuk hayati. Selain tinggi tanaman padi, variabel yang diamati pada penelitian ini adalah jumlah anakan per rumpun. Hasil Uji independent t-test menunjukkan bahwa jumlah anakan perumpun tanaman padi pada petak percontohan memiliki nilai signifikansi sebesar $0,058>0,05 \quad(\alpha=5 \%)$. Hal ini menandakan bahwa jumlah anakan perumpun tanaman padi pada petak percontohan tidak terdapat perbedaan yang signifikan antara jumlah anakan yang menggunakan perlakuan pupuk hayati dengan yang tidak menggunakan perlakuan pupuk hayati.

Hasil penelitian dan pengamatan yang telah dilakukan pada petak percontohan ini dapat disimpulkan bahwa penerapan teknologi penggunaan pupuk hayati pada budidaya padi sawah pertumbuhan tanaman tidak memiliki perbedaan yang nyata pada tinggi tanaman maupun jumlah anakan perumpunnya. Hal ini disebabkan oleh beberapa faktor diantaranya kandungan organik tanah sawah yang masih minim, kemudian penggunaan pupuk organik yang juga masih kurang optimal sehingga pupuk kimia tidak dapat bekerja secara maksimal. Sehingga perlu adanya peningkatan penggunaan pupuk hayati dan di imbangin dengan penggunaan pupuk organik. Pada dasarnya penggunaan pupuk hayati dapat menghemat penggunaan pupuk dan memperkecil biaya produksi karena pupuk kimia yang digunakan akan sedikit berkurang. Selain itu, penggunaan pupuk hayati dapat membantu meningkatkan mikroorganisme tanah dan kandungan organik tanah sawah sehingga mengefisienkan penyerapan unsur hara oleh tanaman dan menyerap residu kimia yang ada di air dan tanah.

\section{KESIMPULAN}

Berdasarkan pembahasan tentang tingkat adopsi penggunaan pupuk hayati pada budidaya padi sawah di Kecamatan Bungursari, Kota Tasikmalaya, dapat disimpulkan bahwa tingkat adopsi penggunaan pupuk hayati pada budidaya padi sawah di Kecamatan Bungursari tergolong kedalam kategori sedang. Kategori sedang dalam hal ini menunjukkan bahwa berdasarkan pengalaman yang telah dimiliki umumnya petani sudah mengetahui tentang pupuk hayati tetapi masih rendah dalam mengambil keputusan maupun implementasi petani di lapangan. Faktor-faktor yang memengaruhi tingkat adopsi penggunaan pupuk hayati pada budidaya padi sawah di Kecamatan Bungursari yaitu Pendidikan formal dengan nilai signifikansi sebesar $0,026<0,05 \quad(\alpha=5 \%)$, keuntungan relatif memiliki nilai signifikansi sebesar $0,001<0,05(\alpha=5 \%)$, dan kerumitan memiliki nilai signifikansi sebesar $0,001<0,05$ $(\alpha=5 \%)$. Strategi yang dapat dilakukan untuk meningkatkan tingkat adopsi penggunaan pupuk hayati pada budidaya padi sawah di Kecamatan Bungursari adalah menggunakan analisis deskriptif dan analisis SWOT. Analisis deskriptif yang digunakan yaitu dengan menggunakan hasil dari analisis deskriptif maupun hasil perhitungan analisis regresi linier berganda. Sedangkan analisis SWOT yaitu menggunakan strategi SO. Strategi SO yang digunakan yaitu dengan memaksimalkan kekuatan untuk memanfaatkan peluang yang ada pada kelompok tani.

\section{DAFTAR PUSTAKA}

Amala, T. A., Chalil, D., \& Sihombing, L. (2014). Faktor-faktor yang berhubungan dengan tingkat adopsi petani terhadap sistem pertanian padi organik (Studi Kasus: Desa Lubuk Bayas, Kecamatan Perbaungan, Kabupaten Serdang Bedagai). Journal of Agriculture and Agribusiness Socioeconomics, 2(11), 112.

Badan Pusat Statistik. (2021). Hasil sensus penduduk 2020 di Provinsi Jawa Barat. Berita Resmi Statistik, 23(06), 1-12.

Hidayatullah, I. T. (2014). Pengaruh kombinasi pupuk hayati cair dengan pupuk npk terhadap populasi azotobacter sp., bakteri pelarut fosfat dan hasil tanaman 
Rafiudin, M., Siswoyo, Maryani, A. : Tingkat Adopsi Penggunaan Pupuk ...

caisim (Brassica juncea, l.) pada inceptisols [Thesis]. Unpad, Bandung.

Muchtar, K., Purnaningsih, N., \& Susanto, D. (2014). Komunikasi partisipatif pada sekolah lapangan pengelolaan tanaman terpadu (SL-PTT). Jurnal Komunikasi Pembangunan, 12(2), 1-14.

Noer, S. D., Zakaria, W. A., \& Murniati, K. (2018). Analysis of production efficiency of upland rice farming in Sidomulyo Subdistrict South Lampung Regency. Jurnal Ilmu-Ilmu Agribisnis, 6(1), 1724.

Novita, S., Denmar, D., \& Suratno, T. (2016). Hubungan karakteristik sosial ekonomi petani dengan tingkat penerapan teknologi usahatani padi sawah lahan rawa lebak di Kecamatan Sekernan Kabupaten Muaro Jambi. Jurnal Sosio Ekonomika Bisnis, 19(1), 1-12.

Padillah, P., Purnaningsih, N., \& Sadono, D. (2018). Persepsi petani tentang peranan penyuluh dalam peningkatan produksi padi di Kecamatan Tabir Kabupaten Merangin Provinsi Jambi. Jurnal Penyuluhan, 14(1), 1-10.

Rimbawati, D. E. M., Fatchiya, A., \& Sugihen, B. G. (2018). Dinamika kelompok tani hutan agroforestry di Kabupaten Bandung. Jurnal Penyuluhan, 14(1), 92 103.
Saraswati, R. (2012). Teknologi pupuk hayati untuk efisiensi pemupukan dan keberlanjutan sistem produksi pertanian. Prosiding Seminar Nasional Pemupukan Dan Pemulihan Lahan Terdegradasi, 29-30.

Sugiyono, P. D. (2013). Metode Penelitian Manajemen. Bandung: Alfabeta, CV.

Sundari, S., Yusra, A. H. A., \& Nurliza, N. (2015). Peran penyuluh pertanian terhadap peningkatan produksi usahatani di Kabupaten Pontianak. Jurnal Social Economic of Agriculture, 4(1), 26-31.

Susanti, D., Listiana, N. H., \& Widayat, T. (2016). Pengaruh umur petani, tingkat pendidikan dan luas lahan terhadap hasil produksi tanaman sembung. Jurnal Tumbuhan Obat Indonesia, 9(2), 75-82.

Utama, S. P., Cahyadinata, I., \& Junaria, R. (2007). Faktor-faktor yang berhubungan dengan tingkat adopsi petani pada teknologi budidaya padi sawah sistem legowo di Kelurahan Dusun Besar Kecamatan Gading Cempaka Kota Bengkulu. Jurnal AGRISEP, 6(1), 1-16.

Yahya, M., Sekolah, D., Penyuluhan, T., \& Medan, P. (2012). Adopsi petani dalam pengelolaan tanaman terpadu padi sawah di Kecamatan Sunggal Kabupaten Deli Serdang Sumatera Utara (in Bahasa). Agrica Extensia, 10(1), 23-28. 